\title{
The Visibility of Children Whose Mothers are Being Sentenced for Criminal Offences in the Courts of England and Wales
}

\author{
Shona Minson and Rachel Condry
}

\begin{abstract}
Set within a general understanding of the judicial interpretation of mitigation, and the development of sentencing guidelines, this article presents a study exploring the visibility of children within the sentencing process, and the way in which judges in the courts of England and Wales regard dependent children as a mitigating factor in sentencing. The findings, taken from the results of an analysis of sentencing transcripts from court cases in England and Wales, indicate that the visibility of children of defendants is increased at the initial sentencing hearing if the judge requests a pre-sentence report. In appellate decisions, the children have enhanced visibility as their limited impact on mitigation at first instance usually forms part of the grounds of appeal. There is, however, divergence on a case by case basis as to their impact on mitigation. In offences where a deterrent theory of punishment underpins the sentencing guidelines, the sentences have higher starting points and judges are less able to take the personal mitigation of the defendant's dependent children into consideration. The discussion then considers the impact of these findings on the broader debates about the punitive impact of maternal imprisonment on children, issues of secondary victimisation, vulnerable populations and human rights.
\end{abstract}

\section{InTRODUCTION}

This article presents the findings of a study exploring the visibility of children within the process of the sentencing of mothers and the ways in which judges in the courts of England and Wales regard dependent children as a mitigating factor. We begin by outlining recent developments in sentencing practice in England and Wales and consider its particular impact on women. We then consider the impact of maternal imprisonment on children to understand the factors that judges might take into account. We then explore the notion of judicial discretion and present our findings from the sentencing transcript study. The article concludes with a discussion of the place of children in the sentencing of mothers. We argue that children of mothers being sentenced need to be more than just visible and that they experience very particular consequences and have very particular vulnerabilities that need to be acknowledged. 


\section{Overview of Sentencing Practice and Its Development IN ENGLAND AND WALES}

Sentencing is the 'expression of moral condemnation in response to rule infringements', ${ }^{1}$ and is shaped by theories of justice and punishment. It takes place either following a guilty plea by a defendant or after a trial at which the defendant is found guilty. The four main theories of sentencing are deterrence, rehabilitation, incapacitation and retribution ${ }^{2}$ but more recently reparation has grown in importance as a sentencing theory. These theories are not complementary and in the development of sentencing law in England and Wales there has historically been a lack of clarity over which theory should prevail. Deterrence and incapacitation are utilitarian theories which value the message a sentence gives to society over the rights or needs of the individual offender, whilst reparation and rehabilitation focus on the needs of both offenders and victims. Retributivist sentencing occupies a middle ground seeking to punish proportionately with regard to both the offence and the offender.

Historically, legislative guidance was not provided to judges, and it was for each judge to determine which sntencing theory and aims should take precedence in each case. However over the past fifteen years changes have taken place which have provided clearer guidance for sentencers. These changes began when the Crime and Disorder Act 1988 created the Sentencing Advisory Panel (SAP), the remit of which, was to draft and consult on sentencing guidelines. The SAP provided these guidelines to the Court of Appeal for consideration, but the Court of Appeal was not obliged to accept the recommendations of the SAP. In reality, in most cases they did accept the guidelines and these informed the issuing of 'guideline judgments'. In 1990 a Government White Paper ${ }^{3}$ promised the establishment of 'a new and more coherent statutory framework for sentencing'. ${ }^{4}$ It promised that the framework would be based on the principle of 'just deserts' according to offence seriousness.

Unfortunately the legislation that followed ${ }^{5}$ did not set out just deserts' or 'proportionality' as the primary rationale ${ }^{6}$ and the judges continued to work without guidance. In 2001, a report commissioned by the Labour Government, ${ }^{7}$ once again recommended a move towards a proportionality rationale, with an emphasis on offence seriousness and the offender's criminal record. The legislation which followed that report ${ }^{8}$

$1 \quad$ Susan Easton and Christine Piper, Sentencing and Punishment, the Quest for Justice (Oxford University Press, 2008) 4.

2 Andrew Ashworth, Sentencing and Criminal Justice (Cambridge University Press, 2010) 78.

3 Home Office, Crime, Justice and Protecting the Public (1990).

4 Ibid, [1.5].

$5 \quad$ Criminal Justice Act 1991 (UK).

6 Ashworth, above n 2, 100.

7 John Halliday, Making Punishments Work: Report of a Review of the Sentencing Framework for England and Wales (Home Office, 2001).

$8 \quad$ Criminal Justice Act 2002 (UK). 
had an ambiguous sentencing provision, ${ }^{9}$ which left judges to balance five different sentencing rationale of equal importance in every sentencing decision:

Any court dealing with an offender [aged 18 or over] in respect of his offence must have regard to the following purposes of sentencing -

a) The punishment of offenders

b) The reduction of crime (including its reduction by deterrence)

c) The reform and rehabilitation of offenders

d) The protection of the public

e) The making of reparation by offenders to persons affected by their offences. ${ }^{10}$

The Criminal Justice Act 2002 established the Sentencing Guidelines Council (SGC) under the chairmanship of the Lord Chief Justice, to give guidance on sentencing. Although the SAP continued to exist, it was the SGC, rather than the Court of Appeal, which became responsible for the issuing of sentencing guidelines. The SGC published guidance in 2004 entitled 'Overarching Principles - Seriousness', ${ }^{11}$ which removed the ambiguity of section 142 by stating that the sentence must start the process of sentencing by considering the seriousness of the offence and '[i]n considering the seriousness of the offence, the court must consider the offender's culpability in committing the offence and any harm which the offence caused, was intended to cause or might foreseeably have caused'. ${ }^{12}$

The development of sentencing guidelines was moved forward again, with the creation of the Sentencing Council ${ }^{13}$ which replaced both the Sentencing Advisory Council and the Sentencing Guidelines Council. Its function is to "promote greater consistency in sentencing, whilst maintaining the independence of the judiciary' ${ }^{14}$ and the guidelines which it produces must be followed unless 'it is in the interest of justice not to do so'. ${ }^{15}$ Since 2009, the Sentencing Council has published twenty-five definitive guidelines which 'provide a structured approach to determining the appropriate sentence while still allowing for judicial discretion'. ${ }^{16}$

\section{A The Impact of Sentencing Development on the Sentencing of Women Offenders}

In England and Wales between 1995 and 2010, the mid-year figure for the female prison population rose by $115 \%{ }^{17}$ and there was an increase

$9 \quad$ Ibid, s 142.

10 Criminal Justice Act 2002 (UK) s 142.

11 Sentencing Advisory Panel, Overarching Principles of Sentencing (2009).

12 Ibid, s 143(1).

13 Coroners and Justice Act 2009 (UK) Part IV.

14 Sentencing Council UK (2013) < http://sentencingcouncil.judiciary.gov.uk/aboutus.htm>.

15 Ibid

16 Ibid.

17 Prison Reform Trust, Bromley Briefings: Prison Factfile (2013) <http://www. prisonreformtrust.org.uk/Portals/0/Documents/Prisonthefacts.pdf>. 
in the number of women sentenced for all offences from 258,600 in 2002 to 289,500 in $2007 .{ }^{18}$ Over the same period there was a decrease in the number of sentenced males of $3 \% .^{19}$

Some of this increase may be explained by the effect of policy changes which disproportionately affected women offenders. The recommendations of the Halliday report ${ }^{20}$ had particular implications for the sentencing of women offenders as 'need' was classed as 'risk' and therefore 'high need' became 'high risk'. The characteristics of women in prison suggest that women offenders are a particularly high need group. Of the female prison population, a quarter have spent time in care as a child, and over half have suffered domestic abuse, ${ }^{21}$ while $53 \%$ report having suffered emotional, physical or sexual abuse as a child compared to $27 \%$ of men. ${ }^{22}$ They are five times more likely to have a mental health concern than women in the general population and may also have drug dependency. ${ }^{23}$ Thirty-seven per cent have attempted suicide ${ }^{24}$ and nearly $40 \%$ have low educational attainment having left school before the age of $16 .^{25}$ In comparison to the male prison population, women prisoners have more psychotic disorders, fewer qualifications and a less stable background. ${ }^{26}$ Levels of anxiety and depression among female prisoners are much higher than within the general female population $-49 \%$ to $19 \%{ }^{27}$ This changed understanding of 'need' resulted in an increase in custodial sentences for women offenders. ${ }^{28}$

Two other outcomes of the Halliday report, that persistent offending became viewed as 'dangerous' and the removal of the presumption that non-violent, less serious property crimes should not result in custodial sentences ${ }^{29}$ have also had a disproportionate effect on women. More than

18 Ministry of Justice, Statistics on Women and the Criminal Justice System, a Ministry of Justice Publication under Section 95 of the Criminal justice Act 1991 (Ministry of Justice, 2009).

19 Ibid.

20 Halliday, above $\mathrm{n} 7$.

21 Baroness Jean Corston, The Corston Report, A Review of Women with Particular Vulnerabilities in the Criminal Justice System (Home Office, 2007).

22 Kim Williams, Vea Papadopoulou and Natalie Booth, Prisoner's Childhood and Family Backgrounds (Ministry of Justice, 2012).

23 E Plugge, N Douglas and R Fitzpatrick, The Health of Women in Prison (2006) <http://www.publichealth.ox.ac.uk/research/prison/2007-02-13.6702780065>; Prison Reform Trust, above n 17.

24 Corston, above $\mathrm{n} 21$.

25 Social Exclusion Unit, Reducing Reoffending by Ex-prisoners (2002) 137.

26 Ibid, 18.

27 Miriam Light, Eli Grant and Kathryn Hopkins, Gender Differences in Substance Misuse and Mental Health among Prisoners (Ministry of Justice, 2013).

28 Anne Worrall, 'Rendering Women Punishable: the Making of a Penal Crisis', in Pat Carlen (ed) Women and Punishment (Willan, 2002) 63; Karen Evans and Sandra Walklate 'The Corston Report: Reading Even Further Between the Lines' (2011) 194 (6-11) Prison Service Journal 10.

29 Barbara Hudson, 'Gender Issues in Penal Policy and Penal Theory', in Carlen, n 28,32 . 
double the number of women than men in prison have no previous convictions and $63 \%$ of women are in prison for non-violent offences, compared to $45 \%$ of men. ${ }^{30}$ According to Ministry of Justice statistics for $2013,{ }^{31}$ most women sentenced to immediate custody are convicted of non-violent offences, with $37 \%$ being sentenced for theft and handling stolen goods, a non-violent, less serious, property crime.

Alongside the direct effects of policy changes has been a criticism that the 'just deserts' rationale has not been applied to women appropriately: 'the sentencing of women seems to show a much looser correlation to the supposed aims of sentencing than does that of men. Sentencing of women offenders also shows far less correlation to the offences they commit than does that of men'. ${ }^{32}$

The outcome has been that, for a variety of reasons, the female prison population has grown exponentially in the last decade, and as many of the women in prison are mothers, there has been an increase in the number of children separated from their mother by imprisonment. The most recent figure estimated that more than 17,240 children were separated from their mothers by imprisonment in $2010 .^{33}$

\section{B Focus on the Sentencing of Women Offenders}

Following the government commissioned Corston Report, ${ }^{34}$ the impact of imprisonment on women has gained greater attention. The 2009 Advice to the Sentencing Council 'Overarching Principles of Sentencing' included a section on 'Women Offenders and Other Equality and Human Rights Issues' and stated: 'It is recognized that many women offenders are particularly vulnerable and that sentencing them within a criminal justice system that primarily has been developed to deal with the majority of offenders, who are male, may sometimes result in unfair treatment and outcomes'. ${ }^{35}$

The review made four recommendations specific to women offenders. These included the principle of an offence being so serious that only custody was justified having a 'special force' in relation to women offenders because of the 'multiple harms that are likely to result from incarceration', and that courts must obtain a pre-sentence report before sentencing a woman offender to custody. That recommendation accords

30 Ministry of Justice Offender Management Caseload Statistics 2009 (The Stationery Office London, 2010) also at <http://www.justice.gov.uk/downloads/ publications/statistics-and-data/mojstats/final-excel-tables-july10.zip>.

31 Ibid.

32 Hudson, above n 29, 22.

33 Stephanie Wilks-Wiffen, Voice of a Child (Howard League for Penal Reform, 2010).

34 Home Office, above n 24.

35 Sentencing Advisory Panel Overarching Principles of Sentencing - Advice to the Sentencing Guidelines Council (2009) 218.68 (online) <http://www.banksr. co.uk/images/Guidelines/Advisory\%20Panel\%20Advice\%20to\%20the\%20Council/ Overaching_principles_of_sentencing.pdf>. 
with the research conducted by Piper, ${ }^{36}$ Easton $^{37}$ and Louerio, ${ }^{38}$ but it has not yet been implemented by the Sentencing Council.

However, despite the development of sentencing guidelines, a continuing emphasis on judicial independence and discretion means that sentencing remains an interpretative, subjective process, and it is within this area of subjectivity and discretion that judges can consider the children of a female offender.

It is usual for defence counsel to make a 'plea in mitigation' on behalf of the defendant prior to sentencing, but this may be extremely limited due to a number of factors. Counsel may be given very little time to take instructions, or may not address the most relevant issues, because they have not been given an indication by the judge of the type of sentence that is being considered. Children may or may not be mentioned in the plea in mitigation, as it is at Counsel's discretion what is included, and if counsel does not understand the relevance to sentence they are under no obligation to enquire about dependents.

There is some guidance from the Court of Appeal on the issue. In $R$ (on the application of $P$ and $Q$ ) $v$ Secretary of State for the Home Department ${ }^{39}$ it was made clear that the human rights of a child under Article 8 (the right to family life) are engaged when the court takes a decision to send a parent to prison. Lord Phillips, Master of the Rolls said in his judgment:

It goes without saying that since 2 nd October 2000 sentencing courts have been public authorities within the meaning of section 6 of the Human Rights Act. If the passing of a custodial sentence involves the separation of a mother from her very young child (or, indeed, from any of her children) the sentencing court is bound ... to carry out the balancing exercise ... before deciding that the seriousness of the offence justifies the separation of mother and child. If the court does not have sufficient information about the likely consequences of the compulsory separation, it must, in compliance with its obligations under section 6(1), ask for more. ${ }^{40}$

In $R v$ Rosie Lee Petherick ${ }^{41}$ those principles were re-stated with nine steps set out for every sentencing court to consider. It affirmed the principle that the court should seek information about any children or dependents who may be affected by a sentence of imprisonment.

$36 \quad$ Christine Piper, 'Should Impact Constitute Mitigation? Structured Discretion versus Mercy?' (2007) Criminal Law Review 141-155.

37 Susan Easton 'Dangerous Waters: Taking Account of Impact in Sentencing' (2008) Criminal Law Review 105-120.

38 Tania Louerio, 'Child and Family Impact Assessments in Court: Implications for Policy and Practice', (Families Outside, 2009).

39 [2001] EWCA Civ 1151.

$40 R$ (on the application of $P$ and $Q$ ) $v$ Secretary of State for the Home Department [2001] EWCA Civ 1151 [79].

41 [2012] EWCA Crim 2214, 3 October 2012. 


\section{Impact of Maternal Imprisonment on Children}

What exactly is the impact that judges might consider when performing the exercise set out above? We know that maternal imprisonment has a particularly devastating impact on children. Children whose mothers are sent to prison will experience sudden separation from their mother, who usually will have been their primary carer before imprisonment. One-third of these mothers are lone parents. ${ }^{42}$ It is not known exactly how many end up in state care, but estimates suggest only $9 \%$ remain with their father ${ }^{43}$ and $5 \%$ stay in the family home. ${ }^{44}$ The separation from their primary caregiver therefore has very practical implications in terms of their residence and the arrangements for their care, and also profound psychological and emotional effects. Mothers who are imprisoned will similarly have to manage sudden separation from their children and the concomitant distress this provokes.

It is incredibly difficult to 'mother' children on the outside from within prison and mothers will find they are very limited in what they can do to help their children, or indeed, have any influence on their lives. There are some very practical barriers to 'mothering' from within prison in England and Wales, including restricted prison visits, limits on telephone calls and other communication, and the likelihood that women will be placed a long way from home due to the smaller number of women's prisons, making visiting more difficult. Furthermore, imprisoned mothers having to manage a strong sense of having failed to live up to a notion of motherhood which, in our society, is strongly idealised and inflexible. They are likely to have to endure strong feelings of shame and guilt about their inability to care for their child. Children, in turn, will experience vicarious shame and stigma stemming from the failure of their mothers to live up to a strong societal perception of what mothers ought to be. ${ }^{45}$ Therefore, although research has shown that imprisonment of either parent has a strong effect on children, imprisonment of a mother can be particularly damaging. ${ }^{46}$

The impact of a sentence of imprisonment thus has very real consequences for children, and judges should be aware of this. However, we argue that the impact of the sentence itself needs to be understood within the context of long trajectories of vulnerability, stretching back before imprisonment - indeed, often as far as the imprisoned mother's own childhood - and forward into the future adult lives of her children. We know

$42 \quad$ Social Exclusion Unit 'Reducing Reoffending by Ex-prisoners' (2002) 137.

43 Home Office, above n 24.

44 Diane Caddle and Debbie Crisp, Mothers in Prison, Home Office Research Findings No 38, Research and Statistics Directorate (Home Office, 1997).

45 Rachel Condry, Families Shamed: The Consequences of Crime for Relatives of Serious Offenders (Willan: 2007); Rachel Condry 'Secondary Victims and Secondary Victimization' in SG Shoham, P Knepper and M Kett (eds) International Handbook of Victimology (Taylor and Francis, 2010).

46 Joseph Murray, Lynne Murray 'Parental Incarceration, Attachment and Child Psychopathology' (2010) 12(4) Attachment and Human Development 289-309. 
that women prisoners often have particularly disadvantaged backgrounds. They are more likely to have grown up in state care, to have experienced sexual or domestic abuse, to have histories of drug or alcohol abuse, and mental health problems. ${ }^{47}$ The vulnerability of women prisoners often extends far back into their childhoods and is entrenched.

Studies that focus on the experiences of prisoners' families are often limited to their experience post-sentence and the impact of imprisonment itself. We suggest it is important to also consider life before the sentence - it is likely that children of female prisoners have grown up with particular vulnerabilities and disadvantage already, not least if their mother has drug or alcohol dependency, a history of violent victimisation, and/ or mental health problems. We might then suggest that these children are already vulnerable before the imposition of maternal imprisonment and unlikely to have the personal or social capital to withstand such an impact. Furthermore, they will be exposed to a long criminal justice process before their mother is imprisoned. Research has shown that the arrest of a parent, pre-court processes, and court itself can all have a significant impact on children. ${ }^{48}$

A body of international research has consistently found that children of imprisoned mothers and fathers experience complex and multiple problems. ${ }^{49}$ Their circumstances are not always known, for example, in schools, and their needs are poorly met. They experience disruption to their care and their relationships, problems with their schooling, health and wellbeing, and stigma and social isolation. One review of 16 studies of the impact of imprisonment on children found that children of prisoners were more likely than other children to show antisocial and mental health problems. However, the review recognised that it was difficult to know whether parental imprisonment actually caused these problems or whether they might have been caused by other disadvantages in children's lives that existed before parental imprisonment occurred. ${ }^{50}$ Being more likely to show antisocial and mental health problems is a very significant issue facing prisoners' children and one that may continue into their future lives. Longitudinal studies have found an association between the imprisonment of a parent and a child's own future criminality. ${ }^{51}$ An analysis of

47 Home Office, above n 24; Williams et al, above n 22; Prison Reform Trust, above n 17.

48 Peter Scharff Smith and Lucy Gampbell, 'Children of Imprisoned Parents' (Danish Institute for Human Rights, 2011).

49 See Joseph Murray and David Farrington, 'The Effects of Parental Imprisonment on Children' (2008) 37 Crime and Justice: A Review of Research 133-206; in the USA, Joyce Arditti, Parental Incarceration and the Family: Psychological and Social Effects of Imprisonment on Children, Parents and Caregivers (New York University Press, 2012); and Jane A Siegel, Disrupted Childhoods: Children of Women in Prison (Rutgers, 2011).

50 J Murray, DP Farrington, I Sekol and RF Olsen, 'Effects of Parental Imprisonment on Child Antisocial Behaviour and Mental Health: a Systematic Review' (2009) Campbell Systematic Reviews 4.

51 David Farrington, Jeremy Coid and Joseph Murray 'Family Factors in the Intergenerational Transmission of Offending' (2009) 19 Criminal Behaviour and Mental Health 109-124. 
the impact of a prison sentence on children of prisoners therefore needs to take account of that impact within a complex historical and social context of entrenched vulnerabilities and disadvantage.

\section{Judicial Discretion and the Application of Personal Mitigation in Sentencing}

'There's a subjective element to it starting from an objective basis'. ${ }^{52}$

It is within the consideration of mitigation that judges can use their discretion to adjust sentence within the prescribed guidelines. Mitigation divides into two categories: offence mitigation, that which makes the offence less serious, and offender or personal mitigation which has been described as being mitigation relating to the impact of sentence upon the offender. ${ }^{53}$ It is within this second category that judges can consider the impact of a sentence on offenders' children and can vary the sentence accordingly.

Studies on the judicial use of personal mitigation in sentencing have found that there is significant variation in the application of mitigating factors to sentencing decisions. ${ }^{54}$ Although sentencing guidelines list factors which can be considered as personal mitigation there is no guidance as to the weight which should be applied to different factors. It may be that that would provide little assistance for judges in any event, as the studies have shown that judges weigh factors very differently when regarded objectively and when set within a case context.

Much of the academic debate around mitigation focuses on whether equality of impact in sentencing is an achievable or desirable aim of sentencing. In circumstances where an offender is likely to suffer from the sentence to a significantly different degree than most other people, there is a case for reducing its length. ${ }^{55}$ At present, sentencing guidelines seem to provide for an 'equal decision-making process in determining a sentence ${ }^{56}$ although a recent study found that judges bring a number of personal factors to their decision-making which affect the equality of their decision-making. ${ }^{57}$

With particular regard to the issue of prisoners' children, the case of Mills $^{58}$ stated that a court should, where possible, take into account whether the offender is a primary carer for a child. Piper has argued for

52 Sheriff quoted in Andrew Millie, J Tombs and M Hough 'Borderline Sentencing: a Comparison of Sentencers' Decision-Making in England and Wales and Scotland' (2007) 7 Criminology and Criminal Justice, 249.

53 Easton and Piper, above n 1, 210.

54 Jessica Jacobson and Mike Hough 'Mitigation: The Role of Personal Factors in Sentencing' (Prison Reform Trust, 2007); and Shona Minson, 'Mitigating Motherhood: A Study of the Impact of Motherhood on Sentencing Decisions in England and Wales' (The Howard League for Penal Reform, 2014).

55 Ashworth, above n 2, 185.

56 Martin Wasik, Emmins on Sentencing (Oxford University Press, 4th ed, 2008) 216.

57 Minson, above n 54.

58 Mills [2002] 2 Cr App R 52. 
the impact on children to be taken into account, even if it leads to more lenient sentences. ${ }^{59}$ Easton found that the impact of dependent children was taken into account only intermittently but argued that impact should be taken into account at the point of punishment, rather than the point of sentencing. ${ }^{60}$ Loueiro's research in Scotland established that stakeholders believed that there should be assessments made of the impact on all minor children when their primary caregiver is sentenced, and that the government should standardise how that impact should be taken into consideration. ${ }^{61}$

At present, the court can ask for a pre-sentence report to be prepared by the probation service and this will furnish the court with information about the defendant's background, home life, health issues if relevant, and employment status and will give the view of the probation service on the defendant's suitability for a non-custodial sentence which would be supervised by the probation service. The 2009 advice to the Sentencing Council recommended that pre-sentence reports should be prepared before sentencing a women offender to custody ${ }^{62}$ however this has not formed part of any sentencing guidelines.

\section{Methodology}

Our purpose in this study is to try to understand the thinking of judges in the sentencing process through a qualitative analysis of the transcripts of Crown Court sentencing remarks by judges who sentenced mothers to imprisonment, and the decisions and remarks made by judges in the Court of Appeal, on appeals on sentence by mothers who have been sentenced to imprisonment. Crown Court transcripts are not published although they are available to the public on application. Court of Appeal decisions are available on the Court of Appeal website. No records are kept of how many mothers are sentenced to imprisonment each year, and it is very difficult to estimate the number of women involved. Many of those who are sentenced are serving short sentences imposed by magistrates courts, and there is no data available on those decisions. We were aided by another researcher working in this area who provided us with transcripts for ten mothers who were sentenced to imprisonment, and 33 who appealed their custodial sentences to the Court of Appeal between 2003 and 2011. These cases were found through daily searches of court lists and newspapers and by placing notices in magazines for women in prison.

$59 \quad$ Piper, above n 36.

60 Easton, above n 37.

61 Loueiro, above n 38, 57.

62 Sentencing Council, above n 35. 


\section{Findings}

\section{A Overview of the Cases}

The sample of 43 cases consisted of 10 from the Crown Court and 33 from the Court of Appeal. Thirty-five of the defendants had entered a guilty plea, with the remaining eight being found guilty after a trial. Twenty-six of the women had no previous criminal convictions, and of the 13 who did, four of those were historic convictions which the courts did not take into account (in four further cases it was unclear whether there were previous convictions or not). Thirty-seven of the defendants had never had a custodial sentence, in the case of five it was unclear from the sentencing remarks whether or not they had previously been imprisoned, and only one woman had served a previous period of imprisonment. Four of the defendants had committed the offences for which they were being sentenced whilst serving a non-custodial sentence for another offence, or whilst serving a suspended sentence of imprisonment. Only four of the women were sentenced for offences of violence, and the longest sentences given were for drug importation and firearms possession, 16 years and seven years respectively.

A number of the women had particular vulnerabilities. Twenty-three of the women were single parents (some because the other parent was in prison), and whether the child had another parent taking a caring role was unclear in 12 cases. Four of the women were recorded as having mental health problems and eight were addicted to drugs or alcohol. Six were recorded as having suffered from domestic violence or abuse and eight were described as having 'unhappy personal circumstances', including caring for severely disabled family members.

\section{B Acknowledgement of the Defendant's Dependent Children in the Sentencing}

\section{Crown Court}

Ten transcripts were from the Crown Court, but in many of the Court of Appeal cases the sentencing remarks of the Crown Court judge were referred to, and so it is possible from these transcripts to find out what happened in a larger number of Crown Court hearings. In 19 cases the children were mentioned in the sentencing remarks and in two they were not. In the remaining cases it was unclear from the transcript whether they had been mentioned at the original sentencing hearing.

In seven cases the Crown Court judge specifically said that the sentence was reduced because of the children. In 10 cases, the children were not considered to be a mitigating factor that should reduce the length of the sentence. The remainder of cases were unclear. When the children were regarded as mitigation, having an impact upon sentencing, it was not due to a clear statement of case law or principle but the judges used 
phrases such as 'act of mercy'63 to explain why they were reducing the sentence.

In twenty of the cases which were appealed, the Appeal Court found that the original sentencing Crown Court had given insufficient weight to the defendant's motherhood as a mitigating factor. For example, the court took such a view in $R v D$ :

there are ... cases in which the stress and disorientation caused to a family by the absence of a parent or other carer may justify either a non-custodial sentence or the suspension of a sentence of imprisonment, particularly where the length of any sentence could properly only be short. ${ }^{64}$

\section{Court of Appeal}

In 27 of the appeal cases the children were specifically mentioned by the judges, leaving only six cases in which the children were not mentioned. In 21 of the 27 appeal cases in which sentence was reduced, the mitigation of dependent children was a specified factor leading to that reduction. We give further consideration to the reasons for this below.

\section{Factors Affecting the Visibility and Acknowledgement of Children in Sentencing}

The analysis considered how two different factors - the use of pre-sentence reports and the second chance afforded by an appeal hearing - affected the visibility and acknowledgement of children within the sentencing process.

\section{The Use of Pre-sentence Reports}

There is no obligation upon a judge to request a pre-sentence report and it remains a matter of judicial discretion. Out of the 43 cases sampled, 31 had pre-sentence reports and reference was made to them in the sentencing remarks either at the Crown Court or Court of Appeal. In four cases, the judge chose not to have a report prepared. In the remaining eight cases it was impossible to tell from the sentencing transcripts whether or not a report had been prepared.

In 19 of the 31 cases with pre-sentence reports, the judge at the Crown court hearing did not follow the recommendation of the pre-sentence report. In one case, the recommendation (for a custodial sentence) was followed. In the remaining 11 cases it was unclear what the recommendation had been, and so it was unknown whether it was followed or not.

At the appeal hearings, there were seven cases in which the Court of Appeal chose to follow the original recommendation of the pre-sentence report for a non-custodial sentence. In 12 cases, they chose not to follow the recommendation for a non-custodial sentence. In the remaining 14 cases it was unclear.

$63 \quad R v$ Gillen (Preston Crown Court, England, Brown J, 2 August 2007) 3.

$64 \quad R v$ Dawson [2011] EWCA 1947 (26 July 2011) 3 [20]. 
A previous study of the Crown court sentencing transcripts found that whether or not the recommendation of the pre-sentence report was followed, the visibility of children within the sentencing process was increased by the preparation of such a report. The likelihood of children being a mitigating factor in sentencing was in turn increased by the children's enhanced visibility ${ }^{65}$ However, in this study it was difficult to see such a clear pattern emerging at the Crown Court level, partly due to gaps in the data. It is of note that the Appeal Court followed the recommendations of the pre-sentence reports in more cases than the Crown Courts, often citing the children as a mitigating factor leading to reduced sentences. This would seem to suggest that the pre-sentence reports have a positive impact on dependent children being acknowledged as a mitigating factor in sentencing.

\section{Appeal Hearings}

Thirty-three transcripts of the sentencing appeal decisions were analysed, and in 26 cases the sentence was reduced or replaced with a suspended or non-custodial sentence. One case was returned to the Crown Court for re-sentencing. Only six of the original decisions were upheld.

In 19 of the appeals, the custodial term was reduced, which in three cases facilitated the immediate release of the woman. Five of the original sentences were replaced with suspended sentences and two were replaced with non-custodial sentences.

As has already been mentioned, in 20 cases the Court of Appeal stated that the lower court had given insufficient weight to the defendants' motherhood as mitigation. This analysis suggests that the children had an increased visibility within the appeal hearings and that appeal judges were applying different weighting to the existence of dependent children as a mitigating factor than were the Crown Court judges.

For example, in a number of those cases the importance of the effect of the sentence upon dependent children as a mitigating factor was treated as an established principle, as the following remarks from judges demonstrate:

a sentencing court should only sentence a mother of children for whom she is the primary carer to a term of imprisonment, after the most careful consideration. ${ }^{66}$

her sentences failed in fact to reflect the well-understood principle that an offender who is the carer of three young children should be sentenced to imprisonment only if that is absolutely necessary, and secondly, if it is, for the shortest term that is conceivably commensurate with the offences in question. ${ }^{67}$

we take the view that, where children are to be taken away from their parents, it may be appropriate to impose a shorter sentence of imprisonment,

$65 \quad$ Minson, above n 54.

$66 \quad R v$ Dawson [2011] EWCA 1947 (26 July 2011) 3 [20].

$67 \quad R$ v Arinze [2010] EWCA Crim 1638 (25 July 2010) 2 [11]. 
to mark the gravity of the offending but to minimise disruption to family life. ${ }^{68}$

In another case, $R v$ Whitehead ${ }^{69}$ was referred to as being a case on the importance of the effect of children of a sentence on imprisonment, acknowledging that such effect may 'tip the balance between an immediate custodial sentence and a sentence which enables a defendant an element of freedom'. ${ }^{70}$ Judges in the Court of Appeal also seemed to be more willing to apply the case law which has established the principle that children's Article Eight rights ${ }^{71}$ should be considered in sentencing decisions. ${ }^{72}$ However, although this was more in evidence than in the Crown Court, from our analysis the Court of Appeal still did not consider these rights in most cases.

Another factor influencing increased visibility on appeal may have been that having sent the mother to prison, counsel for the defendant mother was able to mitigate on the basis of actual hardship suffered by children, rather than anticipated hardship.

The analysis of these transcripts suggests that when Crown courts sentence mothers to imprisonment, a high percentage could be successfully appealed on the basis that the defendant's motherhood was given insufficient weight at first instance. It is arguable from the analysis that the lower courts need to give more weight to motherhood as mitigation in a more principled and systematic way. If this does not happen, then a discriminatory system will remain in place where women who can appeal, notably an option not available to those on short sentences, will have a second chance of having their sentence mitigated by consideration of their children.

\section{Barriers to Motherhood as Mitigation}

Visibility is not the only issue, as even when visible there are reasons why it may not be possible for motherhood to be operational as a mitigating factor in sentencing. Sentencing guidelines and mandatory minimum sentences as prescribed by legislation prevent judges from exercising discretion. The deterrent rationale of sentencing is the driving force behind such minimum sentencing and applies most often to drugs and firearms offences. From analysis of cases in this sample, it is clear that not only are women's vulnerabilities ignored in sentencing in which deterrence is the primary rationale, but they may paradoxically be subject to deterrent sentencing because of their vulnerabilities.

$68 \quad R v$ Gill [2010] EWCA Crim 1455 (5 May 2010) 3 [15] (where the appeal was allowed for a mother who was the sole carer of four young children).

$69 \quad R v$ Whitehead [1999] Cr App R (S) 111.

$70 \quad R v$ Davis [2010] EWCA Crim 594 (24 February 2010) 2 [9].

71 European Convention on Human Rights, as enacted in the Human Rights Act 1988.

72 See $R$ (on the application of $P$ and $Q$ ) $v$ Secretary of State for the Home Department [2001] EWCA Civ 1151, at para 79 and $R v$ Rosie Lee Petherick [2012] EWCA Crim 2214 (3 October 2012). 


\section{Deterrent Sentencing}

The six sentences that were not reduced on appeal were cases of drug importation, firearm possession, systematic long term benefit fraud and misconduct in a public office. Deterrence was given as a reason for both the initial lengthy terms of imprisonment and the decision not to reduce the sentence on appeal in these cases. An issue which arises from the use of deterrent sentencing is that sometimes deterrence is thought important so that the vulnerable are protected from those who would use them in their criminal activities, yet this can cause the vulnerable to be further punished because of their vulnerability.

The principle that the vulnerable are exploited because of their vulnerability has been acknowledged in the sentencing of drug couriers, many of whom are foreign national women with young children. In the appeal against sentence in the case of $R v$ Quarcoo ${ }^{73}$ where the defendant was convicted of the importation of a class A drug and had two small children who were in another country, the judge said:

Couriers are chosen by those who are interested in importing large amounts of drugs in this country so that, first, they appear to be people who will not be picked out by the relevant authorities when they arrive in the United Kingdom and, secondly, because they are people who might be regarded as those who will attract the sympathy either of the authorities or of the courts because of their personal circumstances. ${ }^{74}$

In sentencing for the possession of a firearm the courts are bound by statutory minimums. ${ }^{75}$ Possession of an illegal firearm carries a statutory minimum sentence of five years imprisonment (three years for those under the age of 18), and can only be departed from if there are 'exceptional circumstances'. ${ }^{76}$ The reasoning behind this legislation was explained by the judges in the Court of Appeal in one of the cases in this sample, $R$ $v$ Moses. ${ }^{77}$ In that case, the defendant was 18 years old at the time of sentence (17 years old at the time of the offence) and had an 18-monthold son. The defendant's background was that she had left school at 15 and was pregnant shortly thereafter. She had been found in possession of a firearm which she had been asked to look after by 'some boys'. As a consequence of this offence she had lost her accommodation and the pre-sentence report assessed her risk of re-offending as very low. However, due to the statutory guidelines she was sentenced to three years in a young offenders' institution. On appeal, the judges took the view that her circumstances were 'not exceptional' and that 'regrettably' the sentence could not be reduced. In the judgment Mr Justice Simon said:

It is fair to describe the minimum term provisions of the Firearms Act as harsh and even draconian. However, their purpose is clear: it is to

$73 \quad R v$ Quarcoo $[2010]$ EWCA Crim 1236 (18 May 2010).

$74 \quad R v$ Quarcoo [2010] EWCA Crim 1236 (18 May 2010) 3 [16].

75 Firearms Act 1968 s 5(1)(aba) as amended by the Criminal Justice Act 2003.

76 Firearms Act 1968 s 51A(2).

$77 R v$ Moses [2009] EWCA Crim 2820 (2 December 2009). 
deter people from possessing firearms. Those who use or threaten to use firearms are well aware of the dangers of being found in possession of a firearm, so they target those who appear to them to be less likely to draw attention to themselves: young men or women who may never have been in trouble with the law before, young women who may have a young child or children. It is to deter people from being used in this way that the law is framed as it is. ${ }^{78}$

This was a matter specifically referred to in $R v$ Michelle Edwards. ${ }^{79} \mathrm{In}$ this case, the Court made reference to allowing strong personal mitigation to be treated as 'exceptional circumstances', thereby justifying a departure from the usual sentencing point. The Court stated that it did not want to create a risk that:

those looking for safe havens to keep firearms will recruit, in the way that drug importers do with couriers, persons to keep the guns who have moving and distressing personal circumstances in the hope of eliciting the pity of the court..$^{80}$

In one of the other cases involving firearms in this sample, $R v$ Ocran, ${ }^{81}$ the woman was a single parent to a four-year-old child, and she had recently been released from hospital where she had been accommodated whilst suffering from psychosis. She was undoubtedly a vulnerable person and yet her sentence was not reduced on appeal from the mandatory five years.

Although the rationale of the statutory minimum is commendable in its efforts to dissuade those with firearms from asking or persuading those with particular vulnerabilities to hide their guns, it is questionable whether this is a rationale which will work in practice. It seems that it is those who are more vulnerable who will be persuaded to hide firearms. It is no deterrent to those who need the firearms hidden, and it remains likely that they will continue to seek out those who are least able to say no. When vulnerable women with children are then put in this position it seems entirely wrong, to the judges sentencing them at first instance and at appeal as the cases referred to indicate, that their sentences cannot be reduced.

\section{Increasing Visibility and Acknowledging a Context OF VULNERABILITY}

The purpose of this paper has not been to document the impact of maternal imprisonment on children, but rather to explore the recognition of this impact within the sentencing process and whether children are understood to mitigate a sentence. Our findings suggest that three key stages are important to this process:

$78 \quad R v$ Moses [2009] EWCA Crim 2820 (2 December 2009) 2 [13].

$79 \quad R v$ Michelle Edwards [2006] EWCA Crim 2833, [2007] 1 Cr App R(S)111.

$80 \quad R v$ Edwards [2007 1 Cr App R (S) 111 [18].

$81 \quad R v$ Ocran [201] EWCA Crim 1209 (11 May 2009). 
1. Children must be visible in the sentencing process. That is, the judge needs to be aware that they exist, that their mother is the primary carer, and that a sentence of imprisonment will bring an abrupt end to their existing family arrangements.

2. The judge needs to understand the depth of this impact and the range of complex multiple problems that it might engender. This needs to be further understood within a context of trajectories of vulnerability that stretch back into a family's history, can have great salience prior to imprisonment, and can stretch forward many years into the adult life of the prisoners' child.

3. The judge needs to be free to exercise discretion and not be constrained by mandatory minimum sentences. It is particularly poignant that the very vulnerabilities of a female defendant that need to be recognised in the sentencing process may be used as justification for adhering to a punitive sentence in the name of deterrence.

We would argue that taking the children of defendant mothers into account is important for reasons of social justice. As Hudson has argued, we should strive to do 'less harm' through the criminal justice and penal systems. ${ }^{82}$ Prisoners' children are already experiencing vulnerabilities and are at a disadvantage before the imposition of a sentence on their parent. They have needs which should be recognised and addressed rather than worsened by a penalty for an offence for which they cannot be responsible. The notion of "punishment beyond the legal offender's3 must be taken particularly seriously in relation to children who might experience that punishment as protracted and severe.

Furthermore, as mentioned at the outset of this paper, prisoners' children have protected human rights. Article Eight of the Human Rights Act states that every person has a right to family life. ${ }^{84}$ As referred to above, the Court of Appeal have passed judgments which enshrine the principle that the courts should consider the Article Eight rights of the child before sentencing a mother or primary carer to a period of imprisonment, ${ }^{85}$ but research indicates that this practice is not being followed by the courts. ${ }^{86}$ Our study has shown that some judges are considering the separation between mother and child, and their instinct is to be 'merciful' and reduce sentence length or order a non-custodial sentence, but this is not sufficient to uphold a child's human rights. Instead as case law has set out, there

82 Barbara Hudson, Justice through Punishment: A Critique of the Justice Model of Corrections (Palgrave Macmillan, 1987).

83 Megan Comfort 'Punishment Beyond the Legal Offender' (2007) 3 Annual Review of Law and Social Science 271-296.

84 Human Rights Act (UK) 1988.

$85 \quad R v$ Whitehead [1999] Cr App R (S) 111.

86 Rona Epstein, 'Mothers in Prison: The Sentencing of Mothers and the Rights of the Child' (December 2012) Coventry Law Journal Special Research Report available online at <http://www.makejusticework.org.uk/wp-content/uploads/ Mothers-in-Prison-by-Rona-Epstein.pdf $>$. 
should be a proper balancing exercise undertaken to determine whether on balance the child's right to family life outweighs the need for a custodial sentence.

It is possible that this balancing exercise does not take place as a matter of course in the sentencing hearing of every mother, because the sentencing courts are not cognisant of the impact on family life of a sentence of maternal imprisonment. They lack understanding of the impact both in the immediate and the medium- to long-term and judges should therefore be provided with sufficient information to properly understand the balancing exercise they are being asked to conduct in their administration of justice. It is arguable that pre-sentence reports, coupled with a well-presented plea in mitigation could furnish the court with this information, but without this being a mandatory requirement it is unlikely to be sufficient.

The authors would also recommend that this issue forms a mandatory part of judicial education. If all judges have some level of understanding of the impact on children of maternal imprisonment, they will be able to understand why they must balance this factor in their sentencing decisions.

The removal of a child's primary carer is not something that the state should undertake without proper consideration of the child's needs. It is clear that the current sentencing practices in England and Wales do not accord proper value to the children of defendant mothers, in each and every situation. The disregard for the guidance on performing an Article Eight balancing act arguably discriminates against this vulnerable group, and we would recommend that judicial education coupled with changes to sentencing guidelines be introduced to address this important issue. 